\title{
Determinant of Hypertension, Obesity and Smoking on Stroke Events in Hospital Patients at Regional General Hospital of Rokan Hulu Riau District, 2018 (Epidemiology and Public Health)
}

\author{
Armaliza Permata Sari ${ }^{1}$, Rahayu Lubis ${ }^{2}$, Zulfendri ${ }^{3}$ \\ ${ }^{1}$ Master Student in Faculty of Public Health, Universitas Sumatera Utara, Medan, Indonesia \\ ${ }^{2}$ Lecturer in Faculty of Public Health, Universitas Sumatera Utara, Medan, Indonesia \\ Email: melizapermata92@yahoo.co.id
}

\begin{abstract}
:
Stroke is one of the most dominant non-communicable disease complications that can cause death and disability, the number of sufferers continues to increase. The number one cause of death stroke in Indonesia with a proportion of $15.4 \%$. Many factors can cause a stroke, namely factors that can be modified and factors that cannot be modified. This study aims to determine the determinants of hypertension, obesity, smoking of the incidence of stroke in hospitalized patients at the Regional General Hospital of Rokan Hulu Regency, Riau. This type of research is an observational analytic study with a case-control study design with a total sample of 100 people (50 cases and 50 controls) with a ratio of 1: 1. Sampling was done by purposive sampling and using a questionnaire. The independent variables are hypertension, obesity, and smoking. Hypertension using a sphygmomanometer, Obesity using Body Mass Index (BMI) and smoking using a questionnaire. Data analysis was performed by bivariate analysis using simple logistic regression tests and multivariate analysis using multiple logistic regression tests. The results of bivariate analysis with risk factors for stroke events, the most dominant risk factors were hypertension with a value of $p=$ 0.001 and $(O R=5.441,95 \% C l=2,210-13,397)$, Obesity with a value of $p=0.026$ and $(O R=$ $1,712,95 \% \mathrm{Cl}=0,690-4,244)$, and smoking with $p$ value $=0,037$ and $(\mathrm{OR}=1,822,95 \% \mathrm{Cl}=$ 0,717-4,632). Hypertension is the most dominant risk factor for the incidence of stroke in hospitalized patients in Rokan Hulu District Hospital, while the increased risk of stroke with obesity and smoking is not statistically significant in this study.

Keywords:

stroke; hypertension; obesity and smoking
\end{abstract}

\section{Introduction}

Stroke disease is the most dominant health complication resulting in death and disability. Stroke is a disease that occurs in developing countries and developed countries. Stroke is a blood vessel disease in the brain which becomes a dangerous disease problem by requiring fast assistance (Ministry of Health Republic of Indonesia, 2013). Stroke in the United States is the third leading cause of death after heart disease and cancer. Data in the world shows that 15 million people suffer strokes every year, a large number of 795,000 residents in the United States of America have a stroke and kill nearly 150,000 Americans annually (AHA, 2015). Based on Riskesdas 2013 data, stroke in Indonesia is the first cause of death with a proportion of $15 \%$.

Stroke is a disorder of blood vessels or rupture of blood vessels in the brain so that blood supply in the brain becomes disrupted and results in brain cells die because they do not get oxygen and nutrients. Someone who has a stroke will tend to have a stroke again if the risk factors that are not handled properly. Therefore, efforts are needed for effective prevention that leads to healthy lifestyle and management of risk factors. For this reason it is recommended that 
post-stroke patients can carry out regular therapy and an explanation of the risk factors for stroke.

Stroke risk factors include risk factors that can be controlled and cannot be controlled. Factors that cannot be controlled are: heredity, age, gender, ethnicity / race, for risk factors that can be controlled include: hypertension, diabetes mellitus, heart disease, smoking, physical activity, obesity, and consumption of alcoholic drinks, (Bustan, 2015). While other risk factors include: education, employment and marital status.

Hypertension is one of the main risk factors for all types of stroke whether it's a bleeding stroke or an infarction stroke. Hypertension is in line with the increased risk of stroke (Pinzon \& Asanti, 2010). Sorganvi, et al in India (2014) showed that hypertension increases the risk of stroke by 3.80 times. High blood pressure plays a role in atherosclerotic reactions through the risk of pressure on endotheliocytes and layers in the lining of artery walls caused by the formation of plaque in a person's blood vessels called high blood pressure when blood pressure $\geq 140 / 90$ mmHg (Pinzon \& Asanti, 2010). Research conducted by (Nastiti, 2012) states that there is an influence between the occurrence of strokes with high blood pressure and high blood pressure is the most important cause of the effect on the occurrence of stroke.

Risk Factors affecting the incidence of stroke can also be caused by obesity. Clinically respondents with a history of obesity still have a chance of a stroke by 4.960 times compared to those without a history of obesity. According to Smeltzer obesity is at a higher risk for health complications such as diabetes, heart disease, stroke, hypertension, and other respiratory problems. Obesity can also cause cardiac abnormalities and an increase in cardiac output and left ventricular filling pressure, causing hypertension of the heart muscle because the heart is working harder, the condition will allow a stroke if it is not controlled.

Research links smoking to increase the effects of stroke. Smoking can increase fat oxidation, contain various chemicals and tobacco, tar, pesticides, combustion chemicals, radioactive, atherogenic, hematologic and rheological effects which have been stated as potential factors cause of stroke. The effects of stroke can increase 1.5 times every time you consume 10 cigarettes every day (Olsen in Pinzon \& Asanti 2010).

Based on the medical record data of Rokan Hulu District Hospital, data on male and female stroke patients in 2013-2016 were 592 cases, while in 2017 there were 201 cases. This study aims to determine the determinants of hypertension, obesity, and smoking on the incidence of stroke in inpatients at Rokan Hulu District General Hospital, Riau in 2018.

\section{Research Method}

This type of research is an observational analytic study using a case control study design. The case population in this study were all stroke patients who were hospitalized in Rokan Hulu District General Hospital in 2017. The number of samples was 50 cases and 50 controls, with a case and control ratio of 1: 1, so that the total sample was 100 people. Case samples were taken by purposive sampling.

The research conceptual framework consists of independent variables which include: hypertension, obesity, and smoking and the dependent variable is stroke. Data collected includes primary data and secondary data. Primary data were obtained by conducting direct interviews and direct observation using a questionnaire. While secondary data was obtained from collecting 
documents to deepen the results of interviews obtained from the medical records of the Rokan Hulu District Hospital of Riau. Then the questionnaire and interview will be distributed to the respondents who will be selected according to the study's inclusion and exclusion criteria.

\subsection{Bivariate Analysis}

Bivariate analysis was performed to find out the two relationships between the independent of variable and the dependent of variable that had a significant relationship with the dependent variable using a simple logistic regression statistical test.

Table 1. Frequency Distribution Based on History of Disease (Hypertension, Obesity, and Smoking) in Inpatient Stroke Patients in Rokan Hulu District Hospital, Riau in 2018

\begin{tabular}{lcccc}
\hline Variable Independent & $\begin{array}{c}\text { Cases } \\
\text { (Stroke) }\end{array}$ & $\begin{array}{c}\text { Control } \\
\text { (Not Stroke) }\end{array}$ & Pvalue & $\begin{array}{c}\text { OR } \\
(\mathbf{9 5 \%} \mathbf{C l})\end{array}$ \\
\hline Hypertension & & & & \\
Hypertension & 36 & 14 & $<0,001$ & 5,441 \\
$\quad$ No hypertension & 14 & 36 & & $(2,210-13,397)$ \\
\hline Obesity & 34 & 23 & 0,026 & 1,712 \\
Obesity & 16 & 27 & & $(0,690-4,244)$ \\
$\quad$ No Obesity & & & & \\
\hline Smoke & 37 & 27 & 0,037 & 1,822 \\
Yes & 13 & 23 & & $(0,717-4,632)$ \\
No & & & &
\end{tabular}

Based on Table 1 above it can be seen that hypertension shows that there is a significant influence with the incidence of stroke with $\mathrm{p}=0.001$ and $(\mathrm{OR}=5.441,95 \% \mathrm{Cl}=2,210$ 13,397), Obesity shows that there is a significant effect with the incidence of stroke with $\mathrm{p}=$ 0.026 and $(\mathrm{OR}=1,712,95 \% \mathrm{Cl}=0,690-4,244)$, Smoking shows that there is a significant effect on the incidence of stroke with $\mathrm{p}=0.037$ and $(\mathrm{OR}=1,822,95 \% \mathrm{Cl}=0.717-4,632)$.

\section{Discussion}

\subsection{The influence of hypertension on the incidence of stroke in Rokan Hulu District General Hospital Riau in 2018}

The results of multivariate analysis showed that hypertension was one of the most dominant factors affecting stroke with $\mathrm{p}=0.001$ and $(\mathrm{OR}=5.441,95 \% \mathrm{Cl}=2,210-13,397)$ which meant that there was a significant influence between hypertension and stroke. The results of this study are in line with research conducted by Anwar (2012) about the relationship between history of hypertension and the incidence of stroke, that a history of hypertension is a cause of stroke. The results of Sorganvi, et al in India (2014) hypertension increase the risk of 3.80 times getting stroke. This is because diastolic blood pressure above $100 \mathrm{mmHg}$ will increase the risk of stroke by 2.5 times compared to normal diastolic pressure. Satya and Darmanto's results (2014) stated that individuals with systolic blood pressure $\geq 140 \mathrm{mmHg}$ had a 5.12 times greater risk of stroke and individuals with blood pressure $\geq 90 \mathrm{mmHg}$ had a risk of 3.10 times greater stroke. Khairatunnisa research results (2017) that hypertension is the most dominant factor affecting the occurrence of stroke with an OR value of 4.67 (95\% CI: 1.78 - 12.23). This means that patients who suffer a stroke have a risk of 4.67 times with hypertension compared with those who did not suffer a stroke. Riyadina research results (2013) which states that hypertension as a major determinant of stroke with $\mathrm{OR}=4.20$ (95\% CI $=2.20-8.03)$. According to Burhanuddin (2012) that someone who has hypertension is 3-4 times the risk of having a stroke compared to people who do not have hypertension. History of hypertension is one of the 
risk factors for stroke in early adulthood with a risk of 16.22 times greater stroke than patients who have no history hypertension.

\subsection{Effects of Obesity on Stroke Events}

The results of multivariate analysis found that obesity influences the incidence of stroke with $\mathrm{p}=0.026$ and $(\mathrm{OR}=1,712,95 \% \mathrm{Cl}=0.690-4,244)$,) Sorganvi et. al. (2014) in stroke patients stated that obesity is a risk factor for stroke with an OR value of 2.471 (95\% CI: 1.251 4.877). According to research Suk, et. al. (2003) the relationship of obesity with stroke is clearly seen by measuring abdominal circumference compared to body mass index. Body mass index can decrease with age, so at the time of the study could have measured body mass index has changed much. People with obesity are at risk for stroke, but this risk does not occur directly. Obesity is a risk factor for stroke because it can increase the risk of hypertension, coronary heart disease and diabetes mellitus.

According to Agianto Research (2015) obesity is a risk factor for stroke due to excessive fat tissue throughout the body causing difficulties in blood flow and increased risk of blockage, both of which can cause strokes. Obeistas can occur if a person is overweight, so the size of his fat cells increases and the number increases. This is due to a complex disorder of appetite regulation and energy metabolism that is controlled by several specific biological factors, genetic factors, eating habits, environment and lack of physical activity. affect the incidence of stroke. According to the Winter Research (2008) states that there is a significant relationship between obesity (based on waist circumference) with the risk of stroke with an OR value of $4.25(95 \% \mathrm{Cl}$ 2.65-6.84).

\subsection{Effects of Smoking on Stroke Events}

The results of multivariate analysis found that there was an effect between smoking and stroke incidence with $\mathrm{p}=0.037$ and $(\mathrm{OR}=1.822,95 \% \mathrm{Cl}=0.717-4.632)$. According to Mutmaina research (2012) that smoking will have a stroke 2.68 times compared to nonsmokers. According to research results Riyadina and Rahajeng (2013) that smoking has clearly been associated with 2-4-fold increased risk of stroke. Some researchers conclude the relationship is mediocre, especially in smokers who consume more than 20 cigarettes / day. According to The Stroke Association (2012) that smoking can cause strokes because smoking can bring toxic substances carried by cigarette smoke into the lungs so that narrowing of blood vessels occurs so that the possibility for stroke is greater. Based on literature studies smoking can cause strokes because smoking can carry toxic substances carried by cigarette smoke into the lungs so that narrowing of blood vessels occurs and the likelihood of a stroke is greater.

\subsection{Multivariate Analysis}

Multivariate analysis is used to draw the final conclusions of a study. In this study used multiple logistic regression analysis which aims to determine the effect of the independent variables and the dominant dependent variable that is influential. Independent variables that have no significant effect are automatically excluded from the calculation. In the independent variable used as a candidate in the multiple logistic regression test is a variable from the results of bivariate analysis (simple logistic regression) with a p-value $<0.25$ then the results of each independent variable $\mathrm{p}$ value $<0.05$ then the variables are related and modeling is complete. The method used in multiple logistic regression analysis is the Enter method. The results of multiple logistic regression tests show that as many as 3 variables that influence the incidence of stroke, namely: hypertension, obesity and smoking can be seen in the following table 2 : 
Table 2. The results of multiple logistic regression tests show that as many as 3 variables that influence the incidence of stroke, namely: hypertension, obesity and smoking

\begin{tabular}{|c|c|c|c|c|c|}
\hline \multirow[b]{2}{*}{ Variable } & \multirow[b]{2}{*}{ B } & \multirow[b]{2}{*}{$\boldsymbol{P}$} & \multirow[b]{2}{*}{$\operatorname{Exp}(B)$} & \multicolumn{2}{|c|}{$95 \% \mathrm{Cl}$} \\
\hline & & & & Lower & Upper \\
\hline Hypertension & 1,694 & 0,000 & 5,441 & 2,210 & 13,397 \\
\hline Obesity & 0,537 & 0,246 & 1,712 & 0,690 & 4,244 \\
\hline $\begin{array}{l}\text { Smoke } \\
\text { constant }\end{array}$ & 0,600 & $\begin{array}{r}0,207 \\
-\mathbf{1 , 5 4 0} \\
\end{array}$ & 1,822 & 0,717 & 4,632 \\
\hline
\end{tabular}

The results of the analysis in Table 2 show that all variables analyzed for hypertension, obesity, and smoking had $\mathrm{p}$ values $<0.05$. The most dominant variable affecting the incidence of stroke in Rokan Hulu Riau Regional General Hospital is hypertension because it has the highest $\exp (\mathrm{B})$ value of 5.441 .

\section{Conclusion}

After conducting research and analysis of stroke risk factors in hospitalized patients at Rokan Hulu District General Hospital Riau, it can be concluded that the results of multivariate analysis with multiple logistic regression tests that influence the incidence of stroke are hypertension with an exp value (B) of 5.441 .

\section{References}

Agianto., et al.(2015). Analisis Faktor Risiko Stroke pada Pasien Rawat Inap di RSUD Banjarbaru. Jurnal Studi Ilmu Keperawatan Fakultas Kedokteran Universitas Lambung Mangkurat.

Anwar, T .(2012). Kelainan Jantung Sebagai Faktor Risiko Stroke. Universitas Sumatera Utara

Burhanuddin M, et al. (2013). Faktor Risiko Kejadian Stroke Pada Dewasa Awal (18-40 Tahun) Di Kota Makassar Tahun 2010-2012. Fakultas Kesehatan Masyarakat. Universitas Hasannudin Makassar.

Bustan M. Nadjib.(2015). Manajemen Pengendalian Penyakit Tidak Menular. PT Rineka Cipta. Jakarata.

Darmanto, Agus. (2014). Hubungan Antara Hipertensi Dengan Kejadian Stroke Iskemik Di Bangsal Dan Poliklinik Saraf RSUD Dr.Soedarso Pontianak. Fakultas Kedoteran.Universitas Tanjungpura.

Kemenkes RI. (2013).Pedoman Pengendalian Stroke, Direktorat Pengendalian Penyakit Tidak Menular, Subdit Pengendalian Penyakit Jantung dan Pembuluh Darah, Jakarta.

Mutmaina. Faktor Risiko Stroke Pada Dewasa Awal (18-40 tahun) Di Kota Makasar Tahun 20102012.

Nastiti, D. (2012). Gambaran Faktor Risiko Kejadian Stroke pada Pasien Stroke Rawat Inap di Rumah Sakit Krakatau Medika Tahun 2011. Skripsi. Program Studi Kesehatan Masyarakat. Peminatan Epidemiologi Universitas Indonesia. Jakarta

Pinzon \& Asanti. (2010). Awas Stroke! Pengertian, Gejala, Tindakan, Perawatan dan Pencegahan. Yogyakarta : CV. Andi Offset.

Riset Kesehatan Dasar. (2013). Penyajian Pokok-Pokok Hasil Riset Kesehatan Dasar. Badan Penelitian Pengembangan Kesehatan, Kementerian Kesehatan RI. Jakarta.

Riyadina, W. dan Rahajeng, E. (2013). Determinan Penyakit Stroke. Journal FKM UI

Sari, Maya dian., Khairatunnisa. (2017). Faktor Risiko Yang Berhubungan Dengan Kejadian Stroke Pada Pasien Di RSU H.Sahudin Kutacane Kabupaten Aceh Tenggara. Jurnal Jumantik Volume 2 Nomor 1.

Smeltzer et.al .2010. Brunner \& Suddarth's Textbook Of Medical-Surgical Nursing. USA: Wolters 
Kluwer Health

Sorganvi, Vijaya, M.S. Kulkarni, Deepak Kadeli, Suhasini Atharga. (2014). Risk Factors for Stroke: A Case Control Study, International Journal of Current Reseach and Review, Volume: 06 (03), Page: 46-51.

Suk, Seung-Hang, Ralph L. Sacco, Bernadette Boden-Albala, Jian F. Cheun, John G. Pittman, Mitchell S. Elkind \& Myunghee C. Paik. (2003). Abdominal Obesity and Risk of Ischemic Stroke. Stroke, 34, 1586- 1592.

The American Hearth Association. (2012). Hearth Disease and Stroke Statistic 2012 Update a Report From The American Hearth Association.

The American Hearth Association. (2015). Hearth Disease and Stroke Statistic 2015 Update a Report From The American Hearth Association.

Winter Y. et.al. (2008). Contribution of Obesity and Abdominal Fat Mass to Risk Of Stroke and Transient Ischemic Attacks. AHA journal.39, 3145-3151. 